\title{
DIFFERENTIAL TRAPPABILITY OF SMALL MAMMALS IN THREE HABITATS OF SOUTHEASTERN BRAZIL
}

\author{
VIEIRA, M. V., ${ }^{1}$ GRELLE, C. E. V. ${ }^{1}$ and GENTILE, R. ${ }^{2}$ \\ ${ }^{1}$ Departamento de Ecologia, Universidade Federal do Rio de Janeiro, C.P. 68020, \\ CEP 21941-590, Rio de Janeiro, RJ, Brazil \\ ${ }^{2}$ Departamento de Medicina Tropical, Instituto Oswaldo Cruz, Fiocruz, C.P. 926, \\ CEP 21045-900, Rio de Janeiro, RJ, Brazil \\ Correspondence to: Dr. Marcus Vinicius Vieira, Laboratório de Vertebrados, Departamento de Ecologia, \\ Universidade Federal do Rio de Janeiro, C.P. 68020, CEP 21941-590, Rio de Janeiro, RJ, \\ Brazil, e-mail: mvvieira@biologia.ufrj.br \\ Received May 19, 2003 - Accepted September 23, 2003 - Distributed November 30, 2004
}

\begin{abstract}
We compared the trappability of marked and unmarked individuals in species of marsupials and rodents of three tropical assemblages of small mammals in Brazil. Two studies used trapping grids, one in cerrado and the other in an Atlantic forest reserve, whereas the study in a rural area used transects. In the two studies using trapping grids, marked animals were frequently more trappable than unmarked ones, but in some species this difference was not significant. In the rural area, marked and unmarked animals did not differ significantly. The number of recaptures per resident animal was higher in the two studies using trapping grids than in the rural area where transects were used. Differences in trappability between the three studies might have been caused by differences not only in trapping design (grids vs. transects), but also in the type of trap used, bait, and habitat. Although differential trappability tends to be considered the rule in small mammals, these results suggest that trappability of marked and unmarked animals may be specific for the particular combination of sampling design, field methods, and habitat under study.
\end{abstract}

Key words: marsupials, mark-recapture, population size, rodents, Brazil.

\section{RESUMO}

\section{Capturabilidade diferenciada de pequenos mamíferos em três habitats do Sudeste brasileiro}

A taxa de captura de indivíduos marcados e não-marcados de espécies de marsupiais e roedores foi comparada entre três comunidades de pequenos mamíferos no Brasil. Em dois estudos, foram utilizadas grades de armadilhas, um no cerrado e outro em reserva de Mata Atlântica, e em um estudo em área rural foram utilizados transectos. Nos dois estudos que usaram grades de armadilhas, os animais marcados foram capturados com mais frequiência que os não-marcados, embora em algumas espécies essa diferença não tenha sido significativa. $\mathrm{Na}$ área rural, a captura de animais marcados e não-marcados não diferiu significativamente. O número de recapturas por animal residente foi maior nos dois estudos que usaram grades de armadilha. As diferenças de capturabilidade entre os três estudos podem resultar do uso de grades e transectos de armadilhas, mas também podem ser decorrentes das diferenças entre as armadilhas utilizadas, as iscas e os habitats. Independentemente da causa, a capturabilidade diferencial tende a ser considerada uma regra em pequenos mamíferos, mas os resultados apresentados sugerem que a capturabilidade de animais marcados e não-marcados seja específica da combinação particular de desenho amostral, métodos de campo e habitat de estudo.

Palavras-chave: marsupiais, marcação e recaptura, tamanhos populacionais, roedores, Brasil. 


\section{INTRODUCTION}

Traditional methods used to estimate population size, such as the Lincoln-Petersen and Jolly-Seber estimates, assume homogeneity of capture probabilities, i.e., equal trappabilities between individuals and between sampling periods (Begon, 1979; Pollock, 1981). Even the Jackknife method (Burnham \& Overton, 1979), which allows variation in trappability between individuals due to behavioral differences, assumes constancy of trappabilities in time (Burnham \& Overton, 1979; Pollock, 1981). These assumptions are rarely justified in mark-recapture studies of small mammals. Marked individuals frequently are found to be "trap-prone" or "trap-shy" (review in Tanaka, 1980), but these assumptions are seldom evaluated in mark-recapture studies of small mammals, especially in the tropics.

Herein we compare the trappability of marked and unmarked individuals in marsupial and rodent species of three tropical assemblages of small mammals in Brazil: one in the cerrado, a savannalike habitat; one in an Atlantic Forest reserve; and one in a rural area, which originally was Atlantic Forest.

\section{MATERIAL AND METHODS}

\section{Study areas}

The study site in the cerrado was at the Estação Experimental de Itirapina $\left(22^{\circ} 15^{\prime} \mathrm{S}, 47^{\circ} 49^{\prime} \mathrm{W}\right)$, of the Instituto Florestal do Estado de São Paulo, State of São Paulo, and was studied from September 1985 to September 1986. The study took place in a 150 ha patch with two intergrading physiognomic forms of cerrado, both xeromorphic and semideciduous: campo cerrado (scrub savanna) and cerradão (dry forest) (Eiten, 1972; Lacher et al., 1989; Vieira, 1997).

The study site in the Atlantic Forest reserve was in the Parque Estadual do Rio Doce (PERD) (19 $\left.48^{\prime}-19^{\circ} 29^{\prime} \mathrm{S}, 42^{\circ} 38^{\prime}-42^{\circ} 28^{\prime} \mathrm{W}\right)$, State of Minas Gerais, and was studied from March to October 1994. The study was done in an area locally known as Mata do Vinhático, a secondary forest having a mosaic of habitats, with herbaceous plants in open areas, developed midstory vegetation, and trees 20$25 \mathrm{~m}$ height (Grelle, in press).

The study site in the rural area was in the

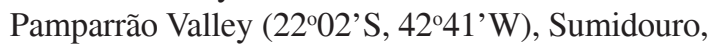
State of Rio de Janeiro, and was studied from June 1991 to September 1996. The valley, which has an area of $1.2 \mathrm{~km}^{2}$, was characterized by small rural properties with diverse plantations, pasturelands, and a few small Atlantic Forest fragments. Several streams, irrigation channels, and some flooded areas occur in the valley (Gentile \& Fernandez, 1999).

The three studies all involved marking and recapturing small mammals, but those carried out in the cerrado and the Atlantic Forest used trapping grids and monthly trapping sessions, whereas that in the rural area employed transects and bimonthly trapping sessions. Trapping sessions lasted six consecutive nights in the cerrado study and five consecutive nights in both the Atlantic Forest and the rural area. Animals were marked by toe-clipping and ear-perforations (for Clyomys bishopi) in the cerrado, toe-clipping and tattooing (for Didelphis aurita and Philander frenatus) in the rural area, and ear-tagging in the Atlantic Forest. The dynamics of these populations are described in elsewhere (Grelle, in press; Vieira, 1997; Gentile et al., 2000).

\section{Sampling methods}

In the cerrado, the grid was 1.32 ha in area with 156 trap stations $10 \mathrm{~m}$ apart. Total trapping effort involved 5928 trap nights, with 78 trap stations every night each trad station had one $30 \times 15 \times 15 \mathrm{~cm}$ Tomahawk trap. During the first three days only the odd-numbered lines of the grid had traps; on the $4^{\text {th }}$ day traps were moved to the even numbered lines, where they remained until the sixth day. The objective of using this technique was to sample an area greater than would have been possible with 78 fixed traps $10 \mathrm{~m}$ apart.

As bait, pieces of banana and sweet potato were used together. In preliminary tests, this combination attracted rodents as efficiently as a mixture of peanut butter and rolled oats.

In the Atlantic Forest, the grid was 3.24 ha in an area with 49 trapping stations $30 \mathrm{~m}$ apart. Each trapping station had three $30 \times 15 \times 15 \mathrm{~cm}$ Tomahawk traps: one on the ground; one 1.5-2.5 m high, wired to a tree, branch, or vine; and another on a platform 5.5-9.0 $\mathrm{m}$ high. The platforms were based on a pulley model (Malcolm, 1991). Fresh pineapple, oatmeal, and a cotton ball soaked with codfish oil were used as bait. Total trapping effort was 5880 trap nights.

In the rural area along a $1.2 \mathrm{~km}^{2}$ valley were spread seven line-transects with traps $13 \mathrm{~m}$ apart. Four transects had 15 trapping stations; two, 10 trapping stations; and one, 5 trapping stations, for a total of 85. Each trapping station had one wire- 
mesh young live trap $(32 \times 18 \times 20 \mathrm{~cm})$ baited with a mixture of peanut butter, banana, oats, and bacon on manioc slices. Total trapping effort was 12250 trap nights.

\section{Trappability and statistical procedures}

Trappability was evaluated by capture rates, defined as the cumulative relative frequency of: 1) first trapping-session recaptures of individuals marked in previous trapping periods; and 2) unmarked individuals captured for the first time (Fleming, 1971; Grodzinski et al., 1966). The cumulative relative frequencies of marked and unmarked animals were calculated for each day of every trapping session, added, and compared with the Wilcoxon test (Zar, 1998). Sample size of marked and unmarked animals was the sum of sample sizes of each trapping session. Animals were considered resident if marked and recaptured at least once.

\section{RESULTS AND DISCUSSION}

In the study in the cerrado, four rodents were compared: Clyomys bishopi (Ávila-Pires \& Wutke, 1981) (Echimyidae), Oryzomys subflavus (Wagner, 1842), Oligoryzomys nigripes (Olfers, 1818), and Bolomys lasiurus (Lund, 1841) (Sigmodontinae). Marked animals generally were more trappable, with capture rates higher than those for unmarked animals (Table 1). This difference was significant in $C$. bishopi, O. subflavus, and O. nigripes. However, for B. lasiurus, marked and unmarked animals did not differ significantly in trappability.

In the Atlantic Forest, three didelphid marsupials were compared: Metachirus nudicaudatus (Desmarest, 1871), Didelphis aurita (Wied-Neuwied, 1826), and Micoureus demerarae (Thomas, 1905). Marked individuals tended to be more frequently captured only in the case of $M$. nudicaudatus, but differences were only marginally significant. In $D$. aurita, unmarked individuals were captured more frequently until the third night of trapping, whereas during the fourth night all marked individuals were captured (Table 1). As for M. demerarae, marked and unmarked individuals were very similar in capture rates (Table 1).

In the rural area, four species were compared: two didelphid marsupials, D. aurita and Philander frenata (Olfers, 1818); and two sigmodontine rodents, Akodon cursor (Winge, 1887) and Nectomys squamipes (Brants, 1827). A different result was noted here, with unmarked animals being more trappable and capture rates generally higher than those for marked animals (Table 1). Differences were marginally significant for three species: $D$. aurita, P. frenata, and $N$. squamipes, but for $A$. cursor the capture rates of marked and unmarked were nearly identical (Table 1). However, when each year was analyzed separately, marked and unmarked individuals of the four species were equally trappable in the rural area (Table 2).

Trappability of marked and unmarked animals varied between the three studies in different directions. In the cerrado marked animals were more trappable (trap-proneness), whereas in the rural area marked and unmarked animals were equally trappable. In the Atlantic Forest there was no clear pattern, but one species, Metachirus nudicaudatus is likely to have been trap-prone (Table 1). Differences in methods between the three studies make it difficult to determine if differences in trappability are habitat-specific, a result of trapping design (grids vs. transects), type of traps used (Tomahawk vs. Young's), baits, use of traps above the ground, or a combination of some or all of these. Differences in species composition between sites could be another hypothesis explaining these results, but it is unlikely that all species of a habitat would respond in the same way if differences were only species-specific.

The possible effect of trapping design on trappability deserves further consideration. Trap-proneness was only found in the two studies using trapping grids, and more extensively in the cerrado. Besides, recaptures per resident animal were always higher in the studies using grids (Table 1), another evidence of a trapping-design effect. Again, this could be attributed to differences in species composition between sites, but individuals of Didelphis aurita were recaptured 8.5 times more frequently in the Atlantic Forest than in the rural area. The designs of the three studies differed in many aspects, but the arrangement of traps (transects vs. grids) and the frequency of trapping sessions (bimonthly vs. monthly) differed between the rural area and the other two sites. Other design aspects did not fit this dichotomy, namely: spacing of trap stations and number of traps per station differed between the study in the Atlantic Forest (30 m, three traps per station) and the other two (10-13 m, one trap per station), grid size differed between the two studies using trapping grids (1.32 vs. $3.24 \mathrm{ha}$ ), and the duration of trapping sessions differed between the study in the cerrado (6 days) and the other two (5 days). 
TABLE 1

Captures rates of marked and unmarked animals of 10 species of small mammals from three localities in Brazil. Individuals were considered resident if marked and recaptured at least once during the studies.

\begin{tabular}{|c|c|c|c|c|c|c|c|c|c|c|c|}
\hline \multirow{3}{*}{ Study site and species } & & \multicolumn{6}{|c|}{ Capture rates per night of trapping session } & \multirow{3}{*}{$N$} & \multirow{3}{*}{$\begin{array}{c}\text { Recaptu } \\
\text { res per } \\
\text { resident } \\
\text { animal }\end{array}$} & \multirow{2}{*}{\multicolumn{2}{|c|}{$\begin{array}{c}\text { Wilcoxon } \\
\text { test statistic } \\
\text { and probability }\end{array}$}} \\
\hline & & \multirow{2}{*}{1} & \multirow{2}{*}{2} & \multirow{2}{*}{3} & \multirow{2}{*}{4} & \multirow{2}{*}{5} & \multirow{2}{*}{6} & & & & \\
\hline & & & & & & & & & & $Z$ & $P$ \\
\hline \multicolumn{12}{|l|}{ Cerrado } \\
\hline \multirow{2}{*}{ Clyomys bishopi } & unmarked & 0.09 & 0.36 & 0.73 & 0.73 & 0.91 & 1.00 & 14 & \multirow{2}{*}{5.44} & \multirow{2}{*}{2.032} & \multirow{2}{*}{0.042} \\
\hline & marked & 0.60 & 0.80 & 0.80 & 0.80 & 1.00 & 1.00 & 9 & & & \\
\hline \multirow{2}{*}{ Oryzomys subflavus } & unmarked & 0.09 & 0.36 & 0.73 & 0.73 & 0.91 & 1.00 & 11 & \multirow{2}{*}{7.60} & \multirow{2}{*}{2.032} & \multirow{2}{*}{0.042} \\
\hline & marked & 0.60 & 0.80 & 0.80 & 0.80 & 1.00 & 1.00 & 5 & & & \\
\hline \multirow{2}{*}{$\begin{array}{l}\text { Oligoryzomys } \\
\text { nigripes }\end{array}$} & unmarked & 0.06 & 0.22 & 0.44 & 0.56 & 0.83 & 1.00 & 18 & \multirow{2}{*}{1.80} & \multirow{2}{*}{2.023} & \multirow{2}{*}{0.043} \\
\hline & marked & 0.40 & 0.60 & 0.70 & 0.90 & 0.90 & 1.00 & 10 & & & \\
\hline \multirow{2}{*}{ Bolomys lasiurus } & unmarked & 0.33 & 0.33 & 0.89 & 1.00 & 1.00 & 1.00 & 9 & \multirow{2}{*}{12.20} & \multirow{2}{*}{0.730} & \multirow{2}{*}{0.465} \\
\hline & marked & 0.60 & 0.80 & 0.80 & 0.80 & 1.00 & 1.00 & 5 & & & \\
\hline \multicolumn{12}{|l|}{ Atlantic Forest } \\
\hline Didolnhic aurita & unmarked & 0.47 & 0.60 & 0.80 & 0.87 & 1.00 & - & 15 & 1040 & 1461 & 0144 \\
\hline 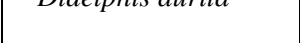 & marked & 0.00 & 0.00 & 0.60 & 1.00 & 1.00 & - & 5 & 10.40 & +01 & $0.1+4$ \\
\hline Metachirus & unmarked & 0.43 & 0.57 & 0.64 & 0.71 & 1.00 & - & 14 & & 1026 & 0060 \\
\hline nudicaudatus & marked & 0.50 & 0.75 & 1.00 & 1.00 & 1.00 & - & 4 & $4.1 J$ & 1.020 & 0.000 \\
\hline Micoureus & unmarked & 0.36 & 0.50 & 1.00 & 1.00 & 1.00 & - & 14 & 710 & 0535 & 0.505 \\
\hline demerarae & marked & 0.50 & 0.80 & 0.80 & 1.00 & 1.00 & - & 10 & & & \\
\hline Rural Area & & & & & & & & & & & \\
\hline Didelnhis & unmarked & 0.31 & 0.55 & 0.73 & 0.90 & 1.00 & - & 142 & 122 & & 0068 \\
\hline 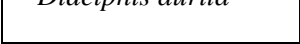 & marked & 0.20 & 0.42 & 0.58 & 0.79 & 1.00 & - & 296 & 1.22 & 1.020 & \\
\hline Philander frenata & unmarked & 0.19 & 0.57 & 0.72 & 0.90 & 1.00 & - & 67 & 133 & -1 & 0068 \\
\hline 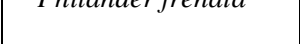 & marked & 0.15 & 0.38 & 0.57 & 0.81 & 1.00 & - & 124 & $1.0 J$ & -1.020 & 0.000 \\
\hline & unmarked & 0.12 & 0.36 & 0.59 & 0.80 & 1.00 & - & 137 & 107 & $<0000$ & 290 \\
\hline 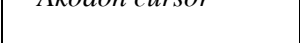 & marked & 0.14 & 0.37 & 0.54 & 0.80 & 1.00 & - & 109 & 1.07 & -0.000 & ארנד \\
\hline Nectomys sauami _ & unmarked & 0.20 & 0.51 & 0.69 & 0.83 & 1.00 & - & 174 & 00 & -1 & 0068 \\
\hline Fectorigs squarmpes & marked & 0.15 & 0.37 & 0.57 & 0.79 & 1.00 & - & 372 & 0. & -1.020 & 0.000 \\
\hline
\end{tabular}

TABLE 2

Wilcoxon test statistic $(Z)$ and associated probability $(P)$ for each year of the study in the rural area.

\begin{tabular}{|l|c|c|c|c|c|c|c|c|c|c|}
\hline & \multicolumn{2}{|c|}{ Year 1 } & \multicolumn{2}{c|}{ Year 2 } & \multicolumn{2}{c|}{ Year 3 } & \multicolumn{2}{c|}{ Year 4 } & \multicolumn{2}{c|}{ Year 5 } \\
\hline \multicolumn{1}{|c}{ Species } & $\boldsymbol{Z}$ & $\boldsymbol{P}$ & $\boldsymbol{Z}$ & $\boldsymbol{P}$ & $\boldsymbol{Z}$ & $\boldsymbol{P}$ & $\boldsymbol{Z}$ & $\boldsymbol{P}$ & $\boldsymbol{Z}$ & $\boldsymbol{P}$ \\
\hline Didelphis aurita & 0.135 & 0.893 & 0.135 & 0.893 & -0.674 & 0.500 & -0.405 & 0.686 & -0.135 & 0.893 \\
\hline Philander frenata & 0.135 & 0.893 & -0.135 & 0.893 & -0.135 & 0.893 & -0.405 & 0.686 & 0.368 & 0.713 \\
\hline Akodon cursor & $<0.000$ & $>0.999$ & 0.405 & 0.686 & 0.135 & 0.893 & $<0.000$ & $>0.999$ & 0.368 & 0.713 \\
\hline Nectomys squamipes & -0.135 & 0.893 & -0.135 & 0.893 & -0.135 & 0.893 & -0.135 & 0.893 & 0.135 & 0.893 \\
\hline
\end{tabular}


The trapping-design effect could occur if resident animals were more likely to find a trap in a grid than in a transect. This would be a consequence of the higher trap density in a grid, and greater trap-proneness by marked animals resident either nearby or within the grid itself. Many recaptures would therefore be registered for resident animals, as observed. Conversely, transects are used to sample an area larger than that possible with a trapping grid, assuming a fixed number of traps and their spacing (in the rural area, seven transects were distributed over a $1.2 \mathrm{~km}^{2}$ valley), and would soon capture and mark a large number of individuals. However, marked individuals would be less likely to be recaptured in transects because of lower trap density. This was observed in the rural area, where the number of individuals captured was much higher than in the other two sites, but the recaptures per individual were lower (Table 1). Accordingly, Read et al. (1988) concluded that traps set along transects tend to capture more species and individuals thereof than in trapping grids.

Regardless of the reason, these results suggest that trappability of marked and unmarked animals may be specific to the particular combination of sampling design, field methods, habitat and species under study. Differential trappability tends to be considered a rule in small mammals (Burnham \& Overton, 1979; Tanaka, 1980), but at least in the yearby-year analysis of the rural area (Table 2), there was no significant difference in trappability between marked and unmarked animals. Traditional methods to estimate population size, such as MNKA (Krebs, 1966), Lincoln-Petersen, and Jolly-Seber will produce different estimates depending on existing trap-proneness. The number of uncontrolled variables in the three studies presented here do not allow for a rigorous comparison between the effects of transect vs. grid trap arrangement, but transects possibly present less bias in trappability and in practice could fulfill the equal trappability assumption of Lincoln-Petersen and Jolly-Seber methods, at least for marked and unmarked animals. However, attention should be paid to other assumptions, such as whether populations are closed (Lincoln-Petersen), and capture-probability constancy in time (Jolly-Seber) (Begon, 1979).

The Jackknife method (Burnham \& Overton, 1979; Pollock, 1981) is recommended particularly for studies where trap-proneness is likely to occur, because it allows heterogeneity of capture probabilities stemming from behavioral differences, and should give a more accurate estimate. Frequently, only MNKA is used because recapture rates or sample size do not allow Jackknife estimates in all sampling periods. In these cases, the Jackknife could at least be used in periods with sufficient sample size for evaluating underestimation of the real population size by MNKA (Grelle, in press; Vieira, 1997; Gentile et al., 2000).

Unmarked individuals were captured until the last night (fifth or sixth) for all species in these studies. More nights of trapping were concluded to be necessary for capturing all individuals in the area, but then the population could not have been considered closed, violating a basic assumption of not only the Jackknife but closed population models in general.

Differential trappability, which might be common in tropical rodents, has been observed in rodents of other regions. However, our results suggest that marked and unmarked animals may be differentially or equally trappable depending on the particular combination of sampling design, field methods, or habitat under study. The occurrence of differential trappability should be checked and not assumed $a$ priori. When differential trappability is detected, estimates of population size based on MNKA should be checked, if not corrected, by use of a method allowing some degree of differential trappability, such as the Jackknife method.

Acknowledgements - M. V. Vieira thanks the employees of the Estação Experimental Itirapina, Instituto Florestal do Estado de São Paulo, and CNPq, CAPES, FAPESP, and FUJB for financial support. C. E. V. Grelle thanks G. Fonseca for guidance in all phases of this study; IEF-MG and ECMVS-UFMG for logistic support; and PRPq-UFMG, PADCT-CIAMB, CNPq, and CAPES for financial support. R. Gentile thanks P. S. D'Andrea, L. Rey, and R. Cerqueira for the existence of the Sumidouro Project; the people of Pamparrão Valley at Sumidouro for allowing field work on their properties; and CNPq, FIOCRUZ, FAPERJ, and FUJB for financial support.

\section{REFERENCES}

BEGON, M., 1979, Investigating animal abundance: capturerecapture for biologists. Edward Arnold, London, 97p.

BURNHAM, K. P. \& OVERTON, W. S., 1979, Robust estimation of population size when capture probabilities vary among animals. Ecology, 60: 927-936.

EITEN, G., 1972, The cerrado vegetation of Brazil. Bot. Rev., 38: 205-341.

FLEMING, T. H., 1971, Population ecology of three species of neotropical rodents. Mis. Pub. Mus. Zool., Univ. Michigan, 143: 1-77. 
GENTILE, R. \& FERNANDEZ, F. A. S., 1999, Influence of habitat structure on a streamside small mammal community in a Brazilian rural area. Mammalia, 63: 29-40.

GENTILE, R., D'ANDREA, P. S., CERQUEIRA, R. \& MAROJA, L. S., 2000, Population dynamics and reproduction of marsupials and rodents in a Brazilian rural area: a five-year study. Stud. Neotrop. Fauna \& Environ., 35: 1-9.

GRELLE, C. E. V., in press. Forest structure and vertical stratification of small mammals in a secondary Atlantic forest, Southeastern Brazil. Stud. Neotrop. Fauna \& Environ., 38.

GRODZINSKI, W., PUCEK, Z. \& RYSKOWSKI, L., 1966, Estimation of rodent numbers by means of prebaiting and intensive removal. Acta Theriol., 11: 297-314.

KREBS, C. J., 1966. Demographic changes in fluctuating populations of (Microtus californicus). Ecol. Monogr., 36: 239-273.

LACHER, T. E., MARES, M. A. \& ALHO, C. J. R., 1989, The structure of a small mammal community in a central Brazilian savanna, pp. 137-162. In: J. F. Eisenberg \& K. H. Redford (eds.), Advances in neotropical mammalogy. Sandhill Crane Press, Gainesville, Florida.
MALCOLM, J. R., 1991, Comparative abundance of Neotropical small mammals by trap height. J. Mammal., 72: 188-192.

POLLOCK, K. H., 1981, Capture-recapture models: a review of current methods, assumptions, and experimental design. Stud. Avian Biol., 6: 426-435.

READ, V. T., MALAFANT, K. W. J. \& MYERS, K., 1988, A comparison of grid and index-line trapping methods for small mammal surveys. Aus. Wild. Res., 15: 673-687.

TANAKA, R., 1980, Controversial problems in advanced research on estimating population densities of small rodents. Res. Pop. Ecol., 2: 1-67.

VIEIRA, M. V., 1997, Dynamics of a rodent assemblage in a cerrado of southeast Brazil. Rev. Brasil. Biol., 57: 99-107.

ZAR, J. H., 1998. Biostatistical analysis. Prentice Hall, Upper Saddle River, New Jersey, $4^{\text {th }}$ ed., 929p. 